\title{
Sometimes What Everybody Thinks They Know Is True
}

\author{
Richard D. Friedman ${ }^{1,3}$ and Roger C. Park ${ }^{2,3}$
}

This essay responds to D. Davis and W. C. Follette (2002), who question the value of motive evidence in murder cases. They argue that the evidence that a husband had extramarital affairs, that he heavily insured his wife's life, or that he battered his wife is ordinarily of infinitesimal probative value. We disagree. To be sure, it would be foolish to predict solely on the basis of such evidence that a husband will murder his wife. However, when this kind of evidence is combined with other evidence in a realistic murder case, the evidence can be quite probative. We analyze cases in which it is virtually certain that the victim was murdered but unclear who murdered her, and in which it is uncertain whether the husband murdered the wife or she died by accident. We show that in each case motive evidence, such as a history of battering or of infidelity, can substantially increase the odds of the husband's guilt. We also consider the actual case on which Davis and Follette base their paper. We argue that testimony of Davis on the basis of the analysis presented in their paper was properly excluded, for it would have been misleading and unhelpful.

KEY WORDS: Bayesian analysis; Daubert; expert testimony; motive evidence; probative value; spousal abuse.

Davis and Follette (2002) have published an ambitious paper contending that evidence of motive to commit murder is far less probative than is ordinarily believed. Their touchstone is a case in which a husband is accused of murdering his wife. In such a case, the prosecution may seek to show motive by offering evidence that the wife's life was heavily insured, that the husband was violent and abusive toward his wife, or that the husband had extramarital affairs. Davis and Follette (2002) dub such evidence "intuitive profiling," and state broadly that "many 'profiling' characteristics currently admitted at trial (such as evidence of battery to support a murder charge) are not probative of guilt" (p. 133 (abstract); cf. id. pp. 143-44). In the case

\footnotetext{
${ }^{1}$ University of Michigan Law School, Ann Arbor, Michigan.

${ }^{2}$ Hastings College of the Law, University of California, San Franscisco, California.

${ }^{3}$ To whom correspondence should be addressed to Richard D. Freidman, Ralph W. Aigler Professor of Law, University of Michigan Law School, Ann Arbor, Michigan 48109; e-mail: rdfrdman@umich.edu, or to Roger C. Park, James Edgar Hervey Professor of Law, Hastings College of the Law, University of California, 200 McAllister Street, San Francisco, California 94102; e-mail: parkr@uchastings.edu.
} 
of infidelity, they conclude that

The fact of infidelity is not probative of whether a man murdered or will murder his wife. In fact, the relative increase in likelihood that an unfaithful man will murder his wife, over the likelihood that a faithful man will murder his wife is so infinitesimal $(.0923 \%)$ as to be totally insignificant. (Davis \& Follette, 2002, p. 139)

We disagree. We believe that although motive evidence alone is not sufficient to establish guilt, it is a useful complement to other evidence of guilt. In the typical murder case there will be other evidence tending to make it at least plausible that the accused is guilty as charged. Most basically, there will almost inevitably be proof of the victim's death under suspicious circumstances, and there will likely be additional evidence such as physical traces or eyewitness testimony linking the accused to the death or proof of incriminating statements by the accused. In such a case, motive evidence is helpful in explaining the crime, because people do not ordinarily commit murder without a discernible motive. The Davis and Follette (2002) view about the infinitesimal probative value of motive evidence could only be sustained in cases in which the only evidence of guilt is motive evidence. Even in such an unrealistic case, the analysis is dubious because, as we will illustrate, items of motive evidence vary in degree and strength, and can interact with other evidence of motive in ways that cannot be captured by a schematic quantitative analysis.

Davis and Follette (2002) principally analyze two hypothetical cases. One of them is a case in which there is no evidence that a murder has occurred at all other than motive evidence-what could be called a prospective case, because their analysis best fits the task of predicting whether a husband will murder his wife in the future. This case does not resemble a realistic criminal case. The second case is one in which the wife has certainly been murdered, and the issue is whether the husband is the perpetrator. This is a realistic case, but Davis and Follette offer a flawed analysis of it.

\section{THE MOTIVE-EVIDENCE-ONLY CASE}

Davis and Follette (2002) point out that about 25\% of married men have had at least one incident of marital infidelity. But uxoricide has a much lower incidence, only about four per million married men each year. Thus, even if we assumed that all uxoricides were committed by men who had been unfaithful, the probability that an unfaithful man would murder his wife is only infinitesimally higher than the probability that a faithful man would murder his wife. Making assumptions that they deem generous to the prosecution, Davis and Follette "conclude that at maximum it is $.0923 \%$ (less than one tenth of $1 \%$ ) more likely than an unfaithful man will murder his wife at some point in their marriage than it is that a faithful man will murder his wife." (Davis \& Follette, 2002, p. 138; emphasis in original)

Thus far, the argument of Davis and Follette (2002) is largely unexceptionable. Seeing how they reach the $.0923 \%$ figure will be useful later, however, in understanding flaws in their approach. They are attempting to determine the theoretical maximum probability of guilt if the husband was unfaithful and the theoretical minimum probability of guilt if the husband was not unfaithful, the differential being 
their index of probative value. ${ }^{4}$ To determine the theoretical maximum probability of murder given infidelity, they divide the base rate of murdered wives per million married men, generously estimated to be 240 ( 4 per year times 60 years) by the base rate of infidelity per million married men, estimated to be 260,000 . This yields .000923 , or $.0923 \%$. This is the maximum possible base rate of murder among unfaithful husbands, assuming that all 240 murders were committed by unfaithful husbands. By force of this assumption that only unfaithful husbands committed uxoricide, the hypothetical base rate of murder among faithful husbands is $0 \%$. Under these assumptions, the difference between the base rate among faithful and unfaithful husbands is $.0923 \%-0 \%$, or $.0923 \%$.

We have some doubts of the value of determining this differential, though no technical disagreement with the method used by Davis and Follette (2002) in doing it. But then they draw the startling conclusion that "based solely on this analysis, one can conclude that infidelity is not usefully probative of the likelihood of uxoricide" (p. 138; emphasis in original). At most, they say, its probative value is "min[u]scule"; given their assumptions, "an inference that a man killed his wife because of evidence that he committed adultery would be incorrect 1,082.33 times for every single time it would be correct at a minimum." (Davis \& Follette, 2002, p. 138; emphasis in original)

Davis and Follette (2002) have shown what few would doubt, that even if an unfaithful husband is more likely to murder his wife than is a faithful husband, the difference is very small, because the vast majority of husbands, unfaithful as well as faithful, do not murder their wives. Thinking prospectively, therefore, knowing only that a man and woman are married, the fact that the husband has been unfaithful alters only to a trivial degree any reasonable assessment of the probability that the husband will murder the wife. ${ }^{5}$ But this analysis elides a critical fact. No one is prosecuted for murder unless there is good reason to believe that the supposed victim has in fact died, and under suspicious circumstances. Davis and Follette conduct an analysis that would be appropriate for prediction (assuming no other evidence was available), and then attempt from that analysis to draw inferences about cases in which a husband is accused of murder and there is other evidence of guilt. (Davis \& Follette, 2002, p. 139)

\footnotetext{
${ }^{4}$ We do not believe that this is a particularly useful index. Assuming the evidentiary factor (infidelity in this case) is not presented, the fact-finder has to make its probability assessment without knowledge of whether the evidentiary factor is true or not. Assuming the factor is presented, the fact-finder makes the assessment on the assumption that it is true. In neither case is the key assessment the probability assuming the factor is not true. The question of how to measure probative value is a difficult one; Friedman has called it "perhaps sterile and certainly arid," (Friedman, 1996, at 1829-1830 note 48). Readers who are nevertheless interested in it might consult the debate in Friedman (1986a); Kaye (1986); and Friedman (1986b). Friedman suggested using the arithmetic difference between the probability of the proposition at issue given the evidence in question and the probability of that proposition absent the evidence. If this index is used, it is crucial to bear context in mind: an item of evidence that might appear to have minuscule probative value given one state of the other evidence, in which the disputed proposition seems highly improbable, might have considerable probative value given another state, in which that proposition seems very plausible. Thus, we argue in this case that absent other substantial evidence of uxoricide, infidelity alters the probability of uxoricide only infinitesimally, but given substantial other evidence the impact of infidelity may be quite large.

${ }^{5}$ This kind of prospective question can be posed at a later time, if all that is known occurred before the event in question. Thus, the style of reasoning would be essentially the same if one asked, "Knowing only that a nineteenth century American husband was unfaithful, what is the probability that he killed his wife?"
} 
Davis and Follette (2002) extend their infidelity analysis to evidence of spousal abuse. They write that "even predictors shown empirically to be strongly associated with a crime (i.e., part of an established scientific profile of those who tend to commit the crime) are not necessarily probative of guilt, given that a crime has occurred" (Davis \& Follette, 2002, p. 143). They note that there is a strong correlation between spousal abuse and uxoricide: $86.7 \%$ of male spouse murders have a history of battery. Hence there is a tendency to assume that a history of battery would be probative in a murder case. They deem this assumption "clearly false" and a "fallacy." (Davis \& Follette, 2002, p. 143) Using the same analysis as that used for infidelity, they note that estimated base rates of battery range from 10 to $30 \%$ and, as before, they estimate the base rate of uxoricide at 240 per million. They then say, "Using these numbers, the probative value of battery as evidence of murder is .0638\% (at the $30 \%$ base rate of battery) and $.2022 \%$ (at the $10 \%$ base rate of battery)." Thus, Davis and Follette estimate that at maximum it is two tenths of $1 \%$ more likely that a batterer will murder his wife than that a nonbatterer will murder his. Therefore, they say, the relevance of battering as evidence of guilt is "virtually nil." (Davis \& Follette, 2002, p. 143$)^{6}$ The error in their logic is the same as with respect to evidence of infidelity. True, even a battering husband is highly unlikely to kill his wife. But that is not the question in real cases. If the wife appears to have been murdered, then a history of battering may be significant evidence tending to point the finger to the husband.

Interestingly, Davis and Follette (2002) appear at some level to be aware of the problem, because their analysis of the probative value of spouse abuse evidence is immediately followed by a caveat that is so different from their main analysis in its purport that one is tempted to infer it was inserted in a different stage of the editorial process, without revising the original analysis. In this caveat, presented under a section entitled "What if the Prior Probability of Guilt is Known?" they note that their analysis was prepared for a case in which it was not known whether the wife died of accident or of homicide. They then write:

\footnotetext{
If it was known that the woman was murdered, our calculations would arguably have to be different, as it has been shown that $50-80 \%$ of murdered women are murdered by their husbands or lovers (e.g., Johnson, 1995). Thus, in the relatively unique circumstance where the probability of guilt for the particular class of defendants is known to be high (husbands in this example), the calculations would have to set the probability of murder at the base rate of guilt ( $50-80 \%$ in this instance), rather than 240 per million, as assumed in our previous illustrations.
}

They do not think that this caveat is very important, because "for most crimes, statistics do not point to a particular person in this way" and therefore "there would be no reason to adjust [the] calculations." (Davis \& Follette, 2002, p. 143, 144) Thus, where the accusation is parricide of an elderly parent, Davis and Follette would appar-

\footnotetext{
${ }^{6}$ This view is reminiscent of one advanced on the Today show by Alan Dershowitz, a consultant for the O. J. Simpson defense. See Saturday Today (1995), available at 1995 WL 2709880. Professor Dershowitz stated that there are 2-5 million cases of spousal abuse every year, but only 1,500 cases of spousal murder, so that $99.9 \%$ of spousal abusers do not murder their wives. Therefore, he said, the spousal abuse evidence in the Simpson case was "massively irrelevant." Dershowitz gives a similar argument at greater length in Dershowitz (2002), pp. 224-232. For a critique of this analysis, see Good (1995), Good (1996), Park (1996), pp. 749-751, Gigerenzer (2002), pp. 141-145. For an analysis of other crimes evidence based on comparative propensity rather than naked base rates, see Park (1998), pp. 723-725, 758-768.
} 
ently regard evidence of a history of battery as having no significant probative value, provided that the frequency of hitting parents is much higher than the frequency of murdering them-unless, under the caveat, there were statistics showing that when parents are killed it is often by their children.

The caveat announced by Davis and Follette (2002) would be more accurate if it were broadened. It is not the presence of statistics indicating how often husbands kill wives that makes their probative value analysis of infidelity and battery evidence inapplicable to real cases. Rather, the presence of any significant evidence making it plausible that a murder has been committed and the accused had a significant relationship with the victim will invest evidence that the accused had a motive to kill the victim, or that the accused had a history of violence with the victim, with substantial probative value. And if there is other evidence pointing to the accusedsuch as statements by him or significant physical evidence-then such motive and propensity evidence may have decisive probative value, enough to take a prosecution case that seemed merely probable across the "beyond a reasonable doubt" threshold. Thus expanded, the caveat would be accurate but the main thesis of Davis and Follette would be trivial.

\section{THE CASE OF CERTAIN MURDER}

Now we will turn to more realistic cases, in which the principal analysis offered by Davis and Follette (2002) cannot apply. We will focus first on the situation presented by their caveat, the case in which it is known that the woman was murdered.

If a base rate of $50 \%$ of husbands whose wives have been murdered are guilty of the crime, Davis and Follette say that the probative value of evidence of infidelity becomes $67.57 \%$ - that is, the husband is $67.57 \%$ more likely to have committed the crime given infidelity than given no infidelity. If the base rate is $80 \%$, they say the probative value is $27.03 \%$. (Davis \& Follette, 2002, p. 143) We will focus on the $50 \%$ case; the logic is the same for the $80 \%$ case.

Although Davis and Follette (2002) speak of the $67.57 \%$ figure as being the probative value of the evidence of infidelity given an assumed base rate of $50 \%$, we believe it actually purports to be the maximum probative value of the evidence in that situation, according to the index used by them. They derive the $67.57 \%$ figure as follows. ${ }^{7}$ A base rate of $50 \%$ means that 500,000 of every 1,000,000 murders of married women are murders by husbands. The base rate for infidelity is 260,000 out of $1,000,000$. Davis and Follette then assume that of a million men whose wives are murdered 260,000 were unfaithful, and, to obtain maximum probative value using their method, that all 260,000 unfaithful husbands murdered their wives. That leaves 240,000 leftover murders to be attributed to the 740,000 faithful husbands out of 1 million total husbands. Dividing 240,000 by 740,000 yields $32.43 \%$ as the minimum

\footnotetext{
${ }^{7}$ Davis and Follette (2002) merely state the $67.57 \%$ conclusion on p. 143 without describing step by step how they derived it. The calculation we present here, adapted from the method described by them earlier in their article (pp. 137-139), reaches the same figure, and also, as shown in the next footnote, the figure of $27.03 \%$ if the assumed base rate is $80 \%$. Accordingly, we are confident that we have reconstructed their logic and calculations.
} 
probability that the faithful husband is guilty, and so the differential $(100 \%-32.43 \%)$ is $67.57 \% .8$

This logic is clearly erroneous. The underlying data used by Davis and Follette indicate that 260,000 out of a million of all husbands are unfaithful, and that in half of those cases in which a wife has been murdered the husband is the guilty person. Essentially, then, they are mixing apples and oranges, fractions with different denominators. The number of uxoricide victims per million marriages is, of course, far less than half a million, and far lower than the number of adulterous men per million marriages.

More realistic numbers, closely tracking the underlying assumptions made by Davis and Follette, would be as follows: out of 1 million married couples, $25 \%$ of the husbands are unfaithful, 480 of the wives are murdered, and $50 \%$ of those murders are uxoricides. ${ }^{9}$ That is, 240 of the wives are murdered by the husbands and 240 by other persons. Now, how much probative value infidelity has in proving the guilt of a husband whose wife has been murdered depends on how those 240 uxoricides and the 240 other murders are distributed among the 750,000 faithful husbands and the 250,000 unfaithful ones. There are a very large number of possible distributions.

Note at the outset that it is easy enough to determine what Davis and Follette (2002) call the maximum probative value of the evidence of infidelity: It is $100 \%$ according to their index, not $67.57 \%$ as they have calculated it. To see this, suppose that all 240 uxoricides are by unfaithful husbands and all 240 victims murdered by persons other than their husbands were married to faithful husbands. In this scenario, the evidence of infidelity is completely dispositive: given fidelity, the probability that the husband committed the murder is 0 , and given infidelity the probability is 1 , or $100 \%$. $^{10}$

We do not regard the theoretical maximum probative value of the evidence as particularly interesting, because it involves unrealistic assumptions. More significant is the actual probative value of the evidence-and that depends on the assumptions we make about how probable murder by the husband is and how probable murder by someone else is given the respective assumptions of fidelity and infidelity. If those assumptions are not supported by hard data, then to be realistic they must be supported by experience and understanding of the world. As a purely theoretical matter, for example, one might suppose that a husband who has been unfaithful is less likely

\footnotetext{
${ }^{8}$ In the $80 \%$ case, the calculation is $1-[(800,000-260,000) / 740,000]=27.03 \%$. Davis and Follette, at 143 , regard it as ironic that their index of probative value is lower in the $80 \%$ case than in the $50 \%$ case, but they do not offer an explanation. We believe this is a product of their choice of index of probative value, as well as of their mistaken analysis. But it is not necessarily surprising that evidence will appear to have lower probative value if the proposition it is offered to prove appears highly probable absent the evidence; probative value may diminish if the proposition the evidence is offered to prove appears to be a foregone conclusion.

${ }^{9}$ That we present varying scenarios in numerical terms does not reflect an attachment to a frequentist view of probability. Rather, we do this because some situations are easier to explain with hypothesized frequentist data rather than with, or supplementing, assessments of probability ranging from 0 to 1 .

${ }^{10}$ The only condition necessary to make infidelity be dispositive of guilt is that all 240 murders by someone other than the husband are of wives of faithful husbands-meaning that if a wife has an unfaithful husband she will be murdered by her husband if by anybody. Under this assumption, infidelity proves guilt to a certainty - even if some faithful husbands murder their wives, making the Davis and Follette (2002) index lower than $100 \%$.
} 
than a faithful one to murder his wife-perhaps because the existence of an open marriage reduces the incentives to commit uxoricide. In such a case, proof of infidelity would usually tend to make it less likely that the husband committed the murder. Or one might suppose that infidelity has no bearing whatsoever on the probability that the husband, or anyone else, will murder the wife. In such a case the evidence of infidelity would have no probative value with respect to the husband's guilt. ${ }^{11} \mathrm{But}$ our knowledge of the world makes us recognize that in fact an unfaithful husband is more likely than a faithful one to murder his wife-both because the infidelity may give the husband an incentive to be free of the wife without the complications of divorce and because the infidelity may reflect antipathy towards the wife, or at least lack of affection for her.

As a more realistic scenario, therefore, suppose that out of 1 million marriages, in one fourth of which the husbands were unfaithful, 40 women are murdered by their faithful husbands and 200 by their unfaithful husbands, and that the 240 cases in which wives are murdered by someone other than their husbands are distributed proportionally between the two groups, 180 of the victims being wives of faithful husbands and 60 being wives of unfaithful husbands. Thus, infidelity is assumed to have a bearing on whether the husband will kill the wife, but not on whether someone else will do so. Note that, whether the husband was faithful or unfaithful, the probability that he would murder his wife, as assessed beforehand, is very small under these assumptions, .0053\% (40/750,000) for the faithful husband and $.08 \%$ $(200 / 250,000)$ for the unfaithful one. But given proof that the wife has been murdered, the evidence of infidelity has substantial probative value, raising the probability that the husband committed the murder from 50 to $77 \%$ (or 200/260). ${ }^{12}$

This exercise emphasizes that the simple base rate information offered by Davis and Follette (2002) does not get us very far; to make confident assertions about how probative a rational fact-finder should regard the evidence of infidelity, we would need good information about the relationship between infidelity and uxoricide. Theoretically possible relationships could reveal the evidence to be completely dispositive (in one direction or the other), at one pole, or utterly worthless, at the other. But the most realistic assumptions suggest that the evidence has significant probative value, even though the vast majority of unfaithful husbands do not kill their wives. ${ }^{13}$

As applied to evidence of spousal abuse, the Davis and Follette (2002) analysis is similarly misleading. In this setting, unlike the one of infidelity, Davis and Follette do provide sufficient data needed for a sound analysis. As noted above, they show

\footnotetext{
${ }^{11}$ Interestingly, evidence of infidelity would also have no probative value in a radically different type of scenario, in which all husbands of murdered women were unfaithful. Then, given proof that the wife was murdered, infidelity would be a foregone conclusion.

${ }^{12}$ Put another way, the evidence raises the odds of guilt from 1:1 to 200:60, or 3.33:1.

${ }^{13}$ Compare this scenario. Of 750,000 faithful husbands, 40 kill their wives and 45 lose their wives to murder by someone else. The comparable numbers for the 250,000 unfaithful husbands are 200 uxoricides and 15 "other" murders. Thus, this is the same as the scenario just discussed in the text except that the 240 uxoricides are compared to a smaller number of "other" murders, leading to an $80 \%$ base rate of uxoricides, which Davis and Follette (2002) regard as the upper bound suggested by research. Now proof of infidelity will raise the probability of uxoricide to $200 / 215$, or $93 \%$, which is arguably close to the "beyond a reasonable doubt" standard. Note that these results are consistent with the principle that, all other things being equal, the higher the probability of guilt before the evidence of infidelity, the higher the probability given the evidence.
} 
that among male spouse murderers a history of battery is several times more likely to be found than among other married males ( $86.7 \%$ vs. $10-30 \%$; p. 143). Suppose that all that is known is that a married woman has been murdered and that on this basis an investigator assesses the probability that she was murdered by her husband at the assumed base rate of $50 \%$. If the investigator then learns that the husband was a batterer, that $86.7 \%$ of all husbands who kill their wives have a history of battery, and that $30 \%$ of other husbands do, the investigator would rationally alter the assessment of the husband's guilt to approximately $74 \%$, corresponding to odds of about 3 to $1 .{ }^{14}$ Of course, in an actual trial more information would be available, and the failure of a prosecutor to introduce any evidence other than marriage and battering would lead to doubt about whether the husband was the perpetrator. But the principle for assessing probative value would be the same: evidence of battering would strongly support other evidence of guilt. This analysis does not fully resolve the question of whether the evidence should be admitted, for that question raises other issues beyond the scope of this essay, but there is no doubt that the battering evidence is probative.

We must emphasize that these exercises are schematic ones. We have treated infidelity and battering as binary matters - a husband is either unfaithful or not, either a batterer or not, and within a given scenario any case of infidelity or of battering has the same probative value. In fact, the matter is much more complex than that, and in part for that reason we doubt that much advantage will be gained by informing the fact-finder of base rates of infidelity or of spousal battery.

\section{THE CASE OF DISPUTED MURDER}

In some cases-including the actual one on which Davis and Follette (2002) base their analysis - the question of whether the decedent was murdered is in dispute. In such a case, as in the case of certain murder, evidence that the accused had a motive to kill the decedent may have significant probative value, in making the hypothesis that the defendant committed the crime more probable in relation to alternative hypotheses. The case of disputed murder includes an alternative hypothesis not present in the case of certain murder - the hypothesis that the decedent was not murdered-but the principle is the same.

There is strong intuitive appeal to the argument that motive evidence has significant probative value. Consider the following question:

Q. A husband is accused of murdering his wife, who died of head trauma with no one else but the husband present. The prosecution presents physical evidence indicating that she was beaten to death. The defendant denies beating her and

\footnotetext{
${ }^{14}$ The prior odds of guilt are 1:1. The likelihood ratio is $.867 / .3$, meaning that the husband is nearly three times as likely to have a history of battering his wife if he murdered her than if he did not. Under Bayes' Theorem, explained briefly below in note 15, the prior odds times the likelihood ratio equal the posterior odds. Given the assumption of prior even odds, the posterior odds simply equal the likelihood ratio. If the prior odds were $4: 1$ (corresponding to a prior probability of $80 \%$ ), the posterior odds would be 11.56:1. For a fuller Bayesian analysis of battery and wife-murder, using different assumed numbers, see Good (1995), revised based on new assumptions in Good (1996).
} 
testifies that he saw her trip and fall down the stairs. Which of the following is true about evidence that the husband severely beat the wife on other occasions?

(1) It has infinitesimal probative value, because battering and nonbattering husbands are alike in that they rarely murder their wives.

(2) It may have significant probative value given evidence that the wife died by either murder or accident, because husbands who do kill their wives are several times more likely to have a history of battering them than are other husbands.

The Davis and Follette (2002) analysis points to (1). (The case is not one of certain murder, and hence does not fall under their caveat about such cases.) We think the answer is clearly (2). ${ }^{15}$

For simplicity, we will analyze a case in which - as in the hypothetical we have just presented and as in the actual case on which Davis and Follette base their analysis-it is uncertain how the wife died, whether by murder or by accident, but essentially certain that if it was by murder the husband was the killer. We will focus on a hypothetical involving infidelity; the analysis is essentially the same for battery.

${ }^{15}$ Indeed, as the evidence is presented here, this result is a simple application of Bayes' Theorem. Under
the odds form of that theorem, the posterior odds of a proposition (the odds assessed in light of a given
piece of evidence) equal the prior odds (the odds assessed absent that evidence) times the likelihood
ratio of the evidence, which is the probability that the evidence would arise given the truth of the
proposition divided by the probability that the evidence would arise given the falsity of the proposition.
In this case, the proposition is that the husband killed the wife and the evidence is that he had a history
of battering her. The evidence is more likely to arise if the proposition is true than if it is false, and so the
likelihood ratio is substantially greater than 1 - somewhere between .867/.1 and .867/.3, according to the
data presented by Davis and Follette. Accordingly, the evidence multiplies the odds that the husband
murdered the wife by at least approximately 3 .
Those data speak of the evidence of battery given, respectively, uxoricide and the absence of uroxicide.
It is sometimes more convenient to transpose the propositions and speak of the probability of uxoricide
given, respectively, the motive-suggesting behavior and the absence of the motive-suggesting behavior,
and our analysis in the following text will take this course. But the two types of analysis are equivalent-
if the probability of evidence of motive-suggesting behavior is greater given uxoricide than given no
uxoricide, then the probability of uxoricide is greater (even if only very slightly) given the motive-
suggesting behavior than given the absence of that behavior, and vice versa. Here is a brief proof
running in one direction; it is generalizable and so could be made to run in the other direction by a
change of labels.
Suppose that $\mathrm{P}(\mathrm{B}$ । U), the probability of battery given uxoricide, is greater than P(B | Not-U). By
Bayes' Theorem, and bearing in mind that the probability of a proposition is 1 minus the probability of
the negation of the proposition, this means that

$$
P(\mathrm{~B}) \cdot P(\mathrm{U} \mid \mathrm{B}) / P(\mathrm{U})>P(\mathrm{~B}) \cdot[1-P(\mathrm{U} \mid \mathrm{B})] /[1-P(\mathrm{U})],
$$

which simplifies to

Now, $P(\mathrm{U})$ equals

$$
P(\mathrm{U} \mid \mathrm{B})>P(\mathrm{U})
$$

and it can also be written as

$$
P(\mathrm{~B}) \cdot P(\mathrm{U} \mid \mathrm{B})+[1-P(\mathrm{~B})] \cdot P(\mathrm{U} \mid \text { Not-B })
$$

$$
P(\mathrm{~B}) \cdot P(\mathrm{U})+[1-P(\mathrm{~B})] \cdot P(\mathrm{U}) .
$$

Setting these two expressions for $P(\mathrm{U})$ equal to each other, and rearranging, we have

$$
0=P(\mathrm{~B}) \cdot[P(\mathrm{U} \mid \mathrm{B})-P(\mathrm{U})]+[1-P(\mathrm{~B})] \cdot[P(\mathrm{U} \mid \text { Not-B })-P(\mathrm{U})] .
$$

Given that all probabilities are between 0 and 1 , and that $P(\mathrm{U} \mid \mathrm{B})>P(\mathrm{U})$, this equation is satisfied if and only if $P(\mathrm{U})>P(\mathrm{U} \mid$ Not-B $)$, and by transitivity this means that $P(\mathrm{U} \mid \mathrm{B})>P(\mathrm{U} \mid$ Not-B $)$. 
Suppose that before learning any information about a husband and wife the factfinder would assess the probability that the husband would kill the wife as $.024 \%$ (or 240/1 million). Further suppose that at that point the fact-finder would assess the probability that the wife would die accidentally in the presence of the husband but of nobody else to be $.024 \%$. Now assume that the wife has been found dead in the presence only of the husband and in circumstances compatible only with murder by the husband or accident; for now assume that the circumstances do not help select between those two hypotheses.

On this information, a rational fact-finder would assess the probability that the husband killed the wife as $50 \%$, corresponding to odds of $1: 1$; before the death, uxoricide and accidental death were equally likely outcomes (both very unlikely), and the death has eliminated all other outcomes without helping to sort between those two.

Now add in proof that the husband was unfaithful. This changes matters, because the fact-finder should no longer be concerned with the probabilities of murder and accidental death for the general run of husbands, but only with the probabilities for unfaithful husbands. Suppose that the husband's infidelity did not affect the probability, as assessed beforehand, that the wife would die accidentally; that was $.024 \%$ whether the husband was faithful or unfaithful. But assume that the husband's infidelity does alter the probability, as assessed beforehand, that he would murder the wife. Suppose as before that there are three faithful husbands for every unfaithful one, and that the 240 uxoricides out of 1 million marriages$.024 \%$ - break down this way: 40 out of 750,000 faithful husbands $(.0053 \%)$ and 200 out of 250,000 unfaithful husbands $(.08 \%)$ murder their wives. Now that we know the husband was unfaithful, we have no use for the information bearing only on cases of faithful husbands; we can concentrate on the unfaithful ones.

Under the assumed facts, the wife of an unfaithful husband is substantially more likely to be murdered by him $(.08 \%$, or 200 out of 250,000$)$ than to die accidentally accompanied only by him $(.024 \%$, or 60 out of 250,000$) .{ }^{16}$ Given the proof of death, in circumstances eliminating all other possibilities but not sorting between those two, the same proportions hold: out of 260 deaths of wives in those circumstances, 200 were murdered by their husbands. The probability is thus $77 \%(200 /(200+60)$, or $.08 /(.08+.024))$ that the husband murdered the wife. Put another way, the odds are 10:3, or 3.33:1 (200:60, or .08:.024) that he murdered her. Thus, the proof of infidelity has had a substantial impact on the probability, given the circumstances of death,

\footnotetext{
${ }^{16}$ These are overall assessments of the probability that a wife would die by uxoricide or by accident. Assessments of the probability that she would die, whether by uxoricide or by accident, in the precise circumstances in which she actually did-the precise time, location, and so forth-would be much smaller, indeed almost unimaginably smaller. This creates something of an intellectual problem but not much of a practical one. If we pose the question, "How likely was it, as assessed beforehand, that a wife would die in the manner we now know she did if the death was by uxoricide, and how likely if it was by accident?" we can include in the term "the manner...she did" only those factors that help sort between hypotheses. For example, that a wife was found drowned in the presence of her husband and no one else was around helps eliminate all hypotheses other than that he killed her and that she died by accident. Whether the death occurred at 4:15:02 or at 4:15:03 in the afternoon does not appear to favor one hypothesis over another.
} 
that the husband murdered the wife, raising it from 50 to $77 \%$; in terms of odds, it has multiplied the odds by 3.33 .

Indeed, if we keep all the assumed numbers constant except for the prior odds of guilt, we find that the evidence of infidelity multiplies those odds, whatever they were, by 10:3. Suppose, for example, that we begin with the assumption that, before learning anything else, the probability is $.24 \%$ that the wife will die accidentally accompanied only by the husband. This means that the prior odds of guilt were 1:10 (.024:.24), corresponding to a $9 \%$ probability. Given the evidence of infidelity, those odds rise to $1: 3(.8: .24)$, the probability to $25 \%$. That is quite substantial.

We concede that, given how common male infidelity is, mere proof that the defendant was unfaithful cannot have the overwhelming degree of probative value that, say, a DNA match can have in a case where identity is at issue. The DNA match may make virtually certain what previously appeared highly improbable. Proof of infidelity, by contrast, can at most make nearly certain guilt that previously would have been plausible. And yet the scenarios presented above suggest that, as with the case of the certain murder, on realistic assumptions the evidence of infidelity will have substantial probative value-not enough absent other evidence pointing rather strongly to guilt for a conclusion of guilt beyond a reasonable doubt, but enough to warrant admissibility as a component of the prosecution's case.

Once again, it is important to emphasize that this exercise is a schematic, simplifying reality for heuristic purposes. Real life is far more complicated than these scenarios. And those complexities sometimes make it difficult to rely, as Davis and Follette (2002) suggest courts should, on base rate data.

We will consider three complexities. First, not all histories of infidelity or of spousal abuse have the same probative value. One extra-marital incident years before, for which the husband showed remorse, might have rather slight probative value; an ongoing affair at the time of the wife's death might have considerably more. Suppose the husband had an extensive history of adultery with many different women. This was a pattern that might lead him to expect that if his wife did not die she would divorce him, and that there might be an ugly battle over money and child custody. Similarly, one old incident in which the husband threw a drink at his wife is likely to have far less probative value than several recent ones in which he beat her to the point of death.

Second, in a real case evidence of matters such as infidelity or abuse often interacts in complex ways with other evidence. Suppose, for example, that the husband purchased a huge amount of insurance on the wife's life shortly before the wife's death, even though the premiums were very expensive given their income. This evidence combines with that of infidelity in an important way. Call it intuitive or not, but a jury would be entirely rational in concluding that a husband who would collect a large insurance payout on the death of his wife (if he is not convicted of murdering her) is far less likely to kill her if he has been faithful to her than if he has not. Insurance alone does not provide much incentive for a loving and loyal husband to murder his wife-spouses usually need not have fear because they are well insured-but it might if the husband regards his wife as unworthy of respect.

In many trials, evidence of infidelity could fit in with other evidence in ways that could not be foreseen by experts prepared to give probative value estimates based on 
base rates-or that, if foreseen, would not properly be the subject of expert testimony because weighing the evidence would not be within their expertise. For example, suppose that there is reason to believe that the wife learned of the infidelity and was contemplating hostile action, such as disinheritance, blackmail, or disgrace before children or parents. The threatened consequences of infidelity might provide an additional motive for murder, different from those of the typical unfaithful husband. In short, infidelity evidence can help the jury understand the story of the relationship in ways that cannot be predicted by experts before trial.

Finally, were the Davis and Follette (2002) analysis accepted as a basis for excluding evidence, still another problem would arise. Jurors would not regard a case in which the prosecution fails to present evidence of motive as merely a case in which nothing was known one way or the other about motive. Instead, they would assume that were there evidence of motive the prosecution would have presented it, and wonder why a husband would murder his wife if he had no motive. Whatever Davis and Follette think about motive evidence, jurors are likely to think that husbands with no motive have much less propensity to murder than husbands who have a motive. In cases in which the prosecution actually had evidence of motive but was prohibited from presenting it, this "missing evidence" inference would be prejudicial to the prosecution. In other words, if inferences from the presence or absence of motive are prejudicial, that prejudice will arise whether the evidence is excluded or not. ${ }^{17}$ Surely exclusion should not be based upon speculative prejudice that, even if it exists, cannot be avoided (Saltzburg, 1978).

\title{
THE FRANKLIN CASE
}

The paper by Davis and Follette (2002) is based on an analysis that they performed in an actual murder case. They describe the case as follows:

\begin{abstract}
We were retained as expert witnesses in the murder trial of a male defendant charged with murder of his wife. The wife had drowned as a result of a snowmobile crash. She was driving the snowmobile with her husband on the back, lost control, and plunged into a ditch. She and the defendant were found by passersby. She was found face down in the water and apparently drowned; and he sitting face up but not breathing - also apparently drowned or unconscious. CPR was administered to both on the scene, and he was successfully revived, whereas she was not.

Prosecution argued that the defendant had deliberately drowned his wife once they had fallen into the ditch, and that he may have somehow caused the crash, thereafter faking his own unconsciousness/inability to breathe. Physical evidence of each of these assertions was extraordinarily weak, particularly evidence of whether the victim's death was the result of murder or accident. (Davis \& Follette, 2002, pp. 135-136.)
\end{abstract}

They then contend that, given the "weakness" in other evidence, the bulk of the prosecution's case consisted of attempts to show that the accused fit the intuitive profile of a spouse murderer, principally by demonstrating his motive through

\footnotetext{
${ }^{17}$ By "prejudice" we are referring here to one type of prejudice postulated by Davis and Follette (2002) prejudice arising from overestimation of the value of high base rate motive evidence. There are other kinds of prejudice - such as passions aroused by motive evidence that also throws the defendant's character in a disreputable light— that could sometimes be avoided by excluding motive evidence.
} 
evidence that he had purchased a large life insurance policy on his wife within the year preceding her death and that he had extramarital affairs with a number of women. (Davis \& Follette, 2002, p. 136)

Deborah Davis was offered as a witness for the defense, but the judge excluded her testimony. As Davis and Follette put it, "Ironically, the judge in our murder case refused to allow testimony to the jury-either on the base rate of infidelity among husbands, or on the implications of this and the base rate of uxoricide for the probative value of evidence of infidelity-on the grounds that the testimony would be prejudicial." (Davis \& Follette, 2002, p. 156, emphasis in original) The jury convicted the defendant and he was sentenced to life in prison. (Keller, 2001, p. 170)

The description given by Davis and Follette (2002) is sufficient to identify the case as People v. Franklin, a California case tried in Plumas County in summer, 2000. In this section we will comment on the Franklin case. Like Davis and Follette, we are trying to illustrate our points in the context of an actual murder case, the one on which their article is based. We will not attempt to describe all the evidence. In fact, we will not describe the evidence introduced by the defense at all, because we are not attempting to retry the Franklin case or to convince the reader that Franklin was guilty. Rather, our immediate goal in this discussion is to show that, notwithstanding the description given by Davis and Follette, the prosecution presented substantial evidence beyond that showing mere motive. In light of this point, we will contend that the expert evidence Davis offered was properly excluded, and we will comment in general on expert evidence of that type.

On the day of her death, Ronna Franklin, who weighed about 150 pounds (Keller, 2001, p. 117), went snowmobiling with her husband Michael, a six-footseven, 300-pound body builder (Keller, 2001, p. 23). ${ }^{18}$ Prosecution evidence indicated that Ronna was reluctant to go snowmobiling, and was perplexed that her husband had bought the vehicle. (Wilson, 2000b) Debra Ingvoldsen, a snowmobiler who first came upon the scene of Ronna's death, testified that the first thing she saw was the Franklins' snowmobile by the side of the road, its motor still running. (Keller, 2001, p. 106) According to her testimony, Michael was sitting in the slush, his face pink and his body steaming, and Ronna was submerged in the slush, with her snowmobile helmet off. (Keller, 2001, p. 106) The slush ranged in depth from 0 to 3 feet deep (Keller, 2001, p. 120, 137), a fact that the prosecutor alluded to in final argument by saying that it would be difficult to drown in it if one tried; all the cold water deaths known to the expert witnesses on either side occurred in deeper water. (Keller, 2001, p. 137, 120) A series of unbroken track marks led from the road to the ditch; there was no sign that the snowmobile had been turned over, and no obvious injuries to either Michael or Ronna. (Keller, 2001, p. 73, 107). Michael appeared to

\footnotetext{
${ }^{18}$ Keller, a journalist from Plumas County, covered the trial for the Feather River Bulletin. (See Keller, 2001, preface and bibliography, unnumbered pages.) Much of Keller's book is devoted to a day-by-day description of events at the trial, including quotations from trial testimony. Although we recognize the danger of journalistic error or bias, Keller's rendition is accurate as far as we know, and we consider it unlikely that he made up evidence out of whole cloth in recounting his county's trial of the century. Even if his account is inaccurate in some particulars, that would not diminish the main point for which we are relying on it, that there was significant evidence of guilt other than motive evidence.
} 
be unconscious, but a witness who was a California Highway Patrol officer "testified that Franklin's eyes suddenly opened when he applied a sternum rub, a technique in which the knuckles are aggressively rasped across the chest of someone to verify whether they're unconscious" (Keller, 2001, p. 107). Michael later told police that he did not remember what happened, except that Ronna had been driving before the accident. Michael did not testify at trial.

The prosecution's theory was that Ingvoldsen had interrupted a crime in progress. The prosecution argued that Michael Franklin intended to drown his wife and then rig an accident, but did not complete his plan before he heard Ingvoldsen approaching on her snowmobile. The Franklins' snowmobile appeared to have been just "parked on the shoulder," without damage, signs of accident, or even signs of sudden braking. (Keller, 2001, p. 73) The prosecution also disputed the defendant's statement to police before trial that Ronna had been driving the snowmobile, relying partly upon witnesses who saw Michael driving it a few minutes before the incident. (Keller, 2001, p. 107, 136-137)

In support of its theory that Michael's unconsciousness was feigned, the prosecution produced testimony indicating that Michael had no injuries. One witness, a prominent neuroradiologist, testified that the CT scans taken of Michael Franklin's head the night of his wife's death showed "no abnormality" and "no evidence of brain injury." Another highly qualified medical expert testified that "the probability is very high that he didn't go unconscious" and that there was "no injury to Mr. Franklin." (Keller, 2001, pp. 110-112)

The motive evidence itself had complexities not captured in the quantitative analysis by Davis and Follette. Michael Franklin appears to have had an extensive history of adultery, with at least a dozen women and perhaps more (Keller, 2001, p. 129; Wilson, 2000c), at one point being involved with nine women simultaneously. (Keller, 2001, p. 129, 139) This was a pattern that may have made him anticipate that if his wife did not die she would divorce him-a prospect that, according to testimony at trial, enraged Franklin, leading him to threaten to kill her if she left him, and that might also have made him fear a fight for custody of their son. (Keller, 2001, p. 23, 128). Moreover, just months before Ronna's death, Michael purchased nearly $\$ 2$ million in insurance on her life, though the premiums were very expensive given their income. (Keller, 2001, p. 27, 66) This insurance evidence combines with the evidence of infidelity in a way that cannot be captured by schematic quantitative analysis. The less the husband respects and loves the wife, the more sharply the financial incentive to murder will be felt. Moreover, Ronna Franklin was the primary earner in the Franklin family (Keller, 2001, p. 27; Wilson, 2000a); her husband may have feared that he would not be able to keep up a lifestyle involving multiple affairs without the aid of her income or the insurance proceeds as a substitute for it.

In short, the prosecution presented substantial evidence, even apart from evidence of motive, that Ronna Franklin died of homicide and that Michael was the killer, and the motive evidence was complex, not easily expressed by a quantitative analysis.

What, then, would have been the effect of Davis's testimony along the lines presented in their article? They offer an accurate analysis of an unrealistic case, in 
which there is no evidence of murder apart from motive-not even evidence of a dead body. They offer a misleading analysis of a realistic case, in which it is clear that the victim was murdered but unclear who committed the crime-and that analysis purports only to show the maximum probative value of the evidence, and shows that it is quite high. They offer no analysis at all that matches the actual Franklin case, in which there was not only a victim who died a sudden and violent death but also substantial and complex evidence apart from motive that the accused murdered her.

Davis's proposed testimony presents a problem that arises with respect to almost any expert testimony about probative value, though not always in the same form or to the same degree. The expert's function is to advise the jury on the value of only a small subset of the evidence in the case. But what that value is may depend critically on the other evidence in the case. The expert has no business telling the jury how to assess that other evidence-and indeed the expert may not know what all that evidence will be and almost certainly does not know how the jury will assess it. This is a complex and intractable problem, and it lies beyond the scope of this essay. But we can say that at a minimum it is essential that the expert testimony address a situation actually presented by the case-and this Davis's proposed testimony failed to do.

Publication of the Davis-Follette theory in a prestigious peer-reviewed journal like Law and Human Behavior increased the probability that expert testimony based on it would be admitted. (The leading case on admissibility of scientifically based expert testimony, Daubert v. Merrell Dow Pharmaceuticals, 1993, specifically listed publication and peer review as factors that cut in favor of admitting expert testimony.) Frankly, we hope our response helps to prevent testimony based on the DavisFollette analysis from being received into evidence. We do not question the good intentions of Davis and Follette, nor do we relish interfering with their choice of professional activities. But when experts come from a genuine academic field, courts depend on other academicians to assess the soundness of their theories. Collegiality is not the only value at stake when assessing expertise that could lead to an incorrect result in a murder case. The judge presiding in the Franklin case was clearly correct in excluding Professor Davis's testimony as prejudicial. Although the case against Franklin was not a slam dunk for the prosecution, it was not a case based purely on motive evidence, and the Davis testimony would have been misleading.

\section{REFERENCES}

Daubert v. Merrell Dow Pharmaceuticals, 509 U.S. 579 (1993).

Davis, D., \& Follette, W. C. (2002). Rethinking the probative value of evidence: Base rates, intuitive profiling, and the "postdiction" of behavior. Law and Human Behavior, 26, 133-158.

Friedman, R. D. (1986a). A close look at probative value. Boston University Law Review, 66, 733-759.

Friedman, R. D. (1986b). Postscript: On quantifying probative value. Boston University Law Review, 66, 767-770.

Friedman, R. D. (1996). Assessing evidence. Michigan L. R., 94, 1810-1838.

Friedman, R. D. (2000). A presumption of innocence, not of even odds. Stanford L. R., 52, 873-887.

Gigerenzer, G. (2002). Calculated risks: How to know when numbers deceive you. New York: Simon \& Shuster.

Good, I. J. (1995). When batterer turns murderer. Nature, 375, 541.

Good, I. J. (1996). When batterer becomes murderer. Nature, 381, 481. 
Johnson, H. (1995). Risk factors associated with non-lethal violence against women by marital partners. In C. Block \& R. Block (Eds.), Trends, risks, and interventions in lethal violence. Proceedings of the third annual spring symposium of the Homicide Research Working Group (pp. 151-168), Atlanta, GA.

Kaye, D. H. (1986). Quantifying probative value. Boston University Law Review, 66, 761-766.

Keller, D. (2001). An almost perfect murder: The saga of Michael Franklin. McLean, VA: IndyPublish.com.

Park, R. C. (1996). Character evidence issues in the O. J. Simpson Case-or, rationales of the character evidence ban, with illustrations from the Simpson Case. University of Colorado. Law Review, 67, 747-776.

Park, R. C. (1998). Character at the crossroads. Hastings Law Journal, 49, 717-779.

Saltzburg, S. A. (1978). A special aspect of relevance: Countering negative inferences associated with the absence of evidence. California Law Review, 66, 1011-1060.

Saturday Today (NBC television broadcast, Jan. 14, 1995), available at 1995 WL 2709880.

Wilson, W. (2000a). Accused killer pursued women always, jury told. Sacramento Bee. June 7, 2000, p. B3.

Wilson, W. (2000b). Woman dreaded Sierra trip, boss testifies, Sacramento Bee. June 28, 2000, p. B4.

Wilson, W. (2000c). Franklin guilty of murder: Jury finds special circumstances true. Sacramento Bee. August 19, 2000, p. B1. 